\title{
How Economic Downturns Affect Children's Development: An Interdisciplinary Perspective on Pathways of Influence
}

\author{
Anna Gassman-Pines, Christina M. Gibson-Davis, and Elizabeth O. Ananat \\ Duke University
}

ABSTRACT-To understand how economic downturns affect children's development, scholars have concentrated on how parents' loss of a job affects children's well-being, but have largely ignored the potential effects of downturns on children whose parents remain employed. In this article, we review research across disciplines to demonstrate that economic downturns should be conceptualized as a community-level event that affects all children in a community, not just those whose parents have lost jobs. We focus on three mechanisms linking downturns to children's developmental outcomes: structural changes to communities, the economic and psychological effects on individuals who are continuously employed, and the strain of job loss on social networks. We conclude by discussing ongoing research and looking at implications for public policy.

KEYWORDS-job loss; unemployment recession

Anna Gassman-Pines, Christina M. Gibson-Davis, and Elizabeth 0. Ananat, Duke University.

Anna Gassman-Pines gratefully acknowledges support from a Foundation for Child Development Changing Faces of America's Children Young Scholars Award, the Sulzberger Family Faculty Fellowship, and the Victoria S. Levin Award for Early Career Success in Young Children's Mental Health Research from the Society for Research in Child Development. Christina M. Gibson-Davis and Elizabeth $O$. Ananat gratefully acknowledge support from the William T. Grant Foundation. We thank Kenneth Dodge, Glen H. Elder, Jr., Erin B. Godfrey, Todd Grindal, Ana Maria Nieto, Soojin Oh, Amanda L. Roy, Carlos Santos, Hirokazu Yoshikawa, Christina Weiland, and Dawn Witherspoon for helpful comments on earlier versions of this article.

Correspondence concerning this article should be addressed to Anna Gassman-Pines, Duke University, Box 90312, Durham, NC 27708; e-mail: agassman.pines@duke.edu.

(C) 2015 The Authors

Child Development Perspectives $\odot 2015$ The Society for Research in Child Development DOI: $10.1111 /$ cdep. 12137
In recent decades, pressures from globalization have moved U.S. job overseas, leading to localized economic downturns across the country. The Great Recession also brought national attention to families' economic vulnerabilities and unease. Together, these local and national events suggest that we need to understand more completely how economic shocks affect children.

Child development scholars have long examined the effects of economic downturns on children by focusing on the consequences of families' loss of employment or loss of income (e.g., $1,2)$. Such changes in families' economic circumstances are linked strongly to individual children's outcomes (1). However, economic downturns should be conceptualized as communitylevel phenomena because most children in communities are affected, not merely those who experience family job loss or income loss directly.

In this article, we examine research across disciplines that highlights the effects of economic downturns on children and on the mechanisms linking downturns to children's outcomes. In our review, we propose a conceptual model for how economic downturns may broadly affect children and families in communities (see Figure 1). Economic downturns can affect all children in a community through structural changes to communities, changes in the economic and psychological well-being of individuals in those communities who are continuously employed, and strains on social networks. Some children, particularly adolescents, may also be affected directly.

We use the term community broadly to incorporate geographic units that are larger than neighborhoods and in which people make decisions about employment, including counties, cities, and states. Although child development scholars have focused on families' individual economic circumstances during downturns, our notion of economic downturns as community-level changes aligns with Bronfenbrenner's ecological systems theory (3), which posits that children's development is influenced by many settings, including in the family and school, among peers, and within the broader community. We build on this theory of 


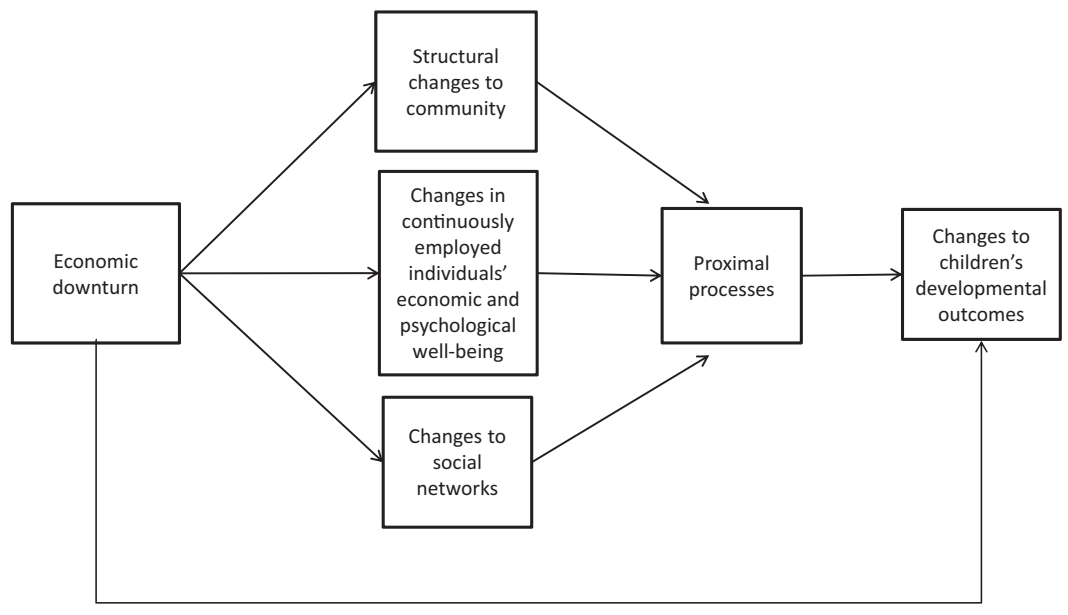

Figure 1. Conceptual model linking economic downturns to the developmental outcomes of all children in a community.

development to broaden developmentalists' understanding of how downturns may affect all children.

First, we define downturns. Then we discuss evidence of downturns' effects on children. Next, we describe three pathways through which downturns may affect children, including individual and geographic differences. Finally, we present implications for ongoing research and public policy.

\section{DEFINING ECONOMIC DOWNTURNS}

No single measure fully summarizes an economic downturn. Scholars have used various measures to operationalize downturns: the unemployment rate, employment-to-population ratio, aggregate job losses, indicators for national recessions, and the consumer confidence index. In this review, we considered studies using each of these measures, focusing on those that measure change in economic circumstances because, across measures, change is central to any definition of an economic downturn. Each definition has strengths and weaknesses, which we summarize in Table Sl. Briefly, change in the unemployment rate is the most commonly used measure and information on such changes is readily available for different geographic units. However, its meaning can be ambiguous (e.g., unemployment falls when discouraged workers stop searching for jobs) and it can be driven by changing community characteristics that also drive outcomes. In contrast, job losses are unambiguously negative events that are generally unrelated to characteristics of workers or communities, but information on the numbers of jobs lost for different geographic units is less available to researchers.

\section{EFFECTS OF ECONOMIC DOWNTURNS ON CHILDREN}

Economic downturns affect a range of outcomes in childhood and adolescence. In our own research and that of others, downturns decreased emotional well-being and school performance, with mixed effects on risk-taking behaviors. For example, as with adults, adolescents' emotional health was harmed by economic downturns: Increases in statewide job losses increased suicide-related behaviors-including suicidal ideation, suicide plans, and suicide attempts_-among female and African American adolescents (4).

Economic downturns also negatively affect children's schoolrelated outcomes. In two studies, increases in the state unemployment rate boosted the odds that students would be retained in a grade (5) and decreased the test scores of 5- to 14-year-olds from lower-income families (6). In different geographic units, communitywide job losses decreased math test scores for students in eighth grade $(7,8)$.

Findings from studies examining adolescents' risk-taking behaviors have been more mixed, with results varying by the definition of economic downturn. Much research shows that economic downturns are associated with less risk-taking. In studies in which downturns are measured by job losses, downturns decreased the birth rate of Black teenagers, decreased teenagers' incidences of engaging in sex with multiple partners and having unprotected sex, and decreased the proportion of adolescents reporting that they had used alcohol $(8,9)$. Changes in states' teenage employment-to-population ratios decreased teenage boys' and girls' likelihood of ever having had sex and of having had sex in the last 3 months, and decreased girls' pregnancy risk (i.e., having had sex in last 3 months without using a condom; 10). These results were consistent with studies of adults, which showed decreased risk-taking and improved health behaviors during recessions (e.g., 11). In contrast, states' overall unemployment rates were related to more risky sexual activity (12) and substance use (13) by adolescents. As mentioned earlier and in Table S1, as a measure of downturns, the overall unemployment rate has weaknesses, which may help explain the discrepancy. 
Economic downturns also affect adolescents directly by altering their perceived employment opportunities, expectations, and worldview. During the Great Recession, adolescents reported more collectivist attitudes, compared to the years immediately preceding the recession (14). Similarly, recessions increased young adults' support for government redistribution, increased their belief in luck versus work in determining success, and lowered their confidence in government institutions (15). These direct effects on adolescents' attitudes may lead to changes in adolescent behaviors, such as risk-taking.

In research on communitywide job losses, children's developmental outcomes were affected over and above what would be expected from effects only on children whose parents had lost jobs $(4,7,8)$. For example, statewide job losses to $1 \%$ of the working-age population decreased the math test scores of eighth-grade students by .076 SDs. If the aggregate effect were driven only by changes in the test scores of the $1 \%$ of students whose parents had lost jobs, those students' test scores would have decreased by $7.6 S D \mathrm{~s}$, an implausibly large effect. More likely, children whose parents did not lose jobs were also affected by the downturns.

\section{PATHWAYS OF COMMUNITY-LEVEL INFLUENCE}

Next, we explore three pathways through which economic downturns may affect children. Each mechanism may have unique consequences for children's development and will likely affect children through more proximal processes, such as parent-child interactions (3; see Figure 1).

\section{Structural Changes to Communities}

During economic downturns, communities undergo structural changes that can affect all children regardless of whether their families face unemployment. Countywide job losses reduced the viability of the local economy by decreasing property values and tax revenues throughout the county (16), which could have lowered public schools' resources. Similarly, during the Great Recession, states with the largest increases in unemployment also had lower levels of government spending, particularly on education (17; school spending is linked strongly with positive academic and behavioral outcomes for children; 18).

The availability and adequacy of other community resources, such as social services, could also be affected. Job losses increased individuals' use of public assistance, as well as their use of other social services, in both counties and states (19). Public assistance increased substantially in the United States during the Great Recession, compared to the prerecession period (e.g., 20). If a community's social services were strained or changed the focus to assist dislocated workers, these structural changes could have affected children in those communities (21).

\section{Economic and Psychological Effects on Continuously Employed Individuals}

The effects of individuals' job losses on earnings and psychological well-being have been studied extensively; job loss decreased earnings both immediately and over the long-term (22), and increased psychological distress and mental health problems (23). Here, we focus on the effects of economic downturns on those who remain employed-which includes most adults, even in severe downturns. Continuously employed adults also earned less and had more psychological distress during downturns $(24,25)$. Such changes affect children's development, as each has been linked to children's outcomes across domains $(2,26)$.

During downturns, earnings may decrease among continuously employed adults for two reasons. First, when unemployment is high, employers can pay their workers less because employers are less concerned about their workers leaving to pursue employment elsewhere. Second, businesses' production may decline, leading to reduced wages. For example, people may order more modest meals at restaurants; wait staff then earn less because they receive lower tips.

For continuously employed adults, economic downturns led to increased symptoms of psychological disorder, lower levels of well-being, and less optimal mood (e.g., 25, 27). Decreased psychological well-being among continuously employed adults during economic downturns could have a number of causes, but two likely factors were changes within workplaces and increased subjective economic strain. After layoffs, the quality of work environments declined, including decreased support by supervisors and increased conflict in the workplace (28). These changes likely decreased workers' psychological well-being, as remaining employed in a business that downsized or laid off workers increased feelings of demoralization and mental health problems (29). Economic downturns also increased uncertainty about the future, leading to subjective economic strain. During the Great Recession, many people perceived economic strain even when they reported no objective economic hardship, and that strain was linked to negative behavioral outcomes in children (30).

Within families, increased financial and psychological stress altered family interactions either directly or through increases in parents' distress (2). Increases in citywide unemployment rates and decreases in the national consumer confidence index predicted increases in mothers' reports of harsh parenting $(31,32)$. In studies of the effects of downturns on one severe type of negative family interaction, child maltreatment increased in general (e.g., 33), with job losses in male-dominated industries leading to higher rates of maltreatment (34).

\section{Strain on Social Networks}

Economic downturns may also affect social networks - the array of social relationships and links among people, such as extended families, coworkers, and friends. When members of social net- 
works lose jobs, those who remain employed may face increased demands to provide social, financial, or instrumental support. During the Great Recession, private transfers (individuals giving cash to other individuals) increased, as did the incidence of families doubling up (i.e., living together in a single household; $35,36)$. Increases in unemployment within states boosted private transfers (37). Providing financial or instrumental support to others could over time lead to increased economic strain for those who remain employed.

Additionally, during economic downturns, individuals may feel distress for members of the social network who have lost work. Although this question has not been examined directly in the context of economic downturns, in one study, members of social networks were almost as upset about many different negative life events experienced by others in their network as they were about their own negative life events (38).

In addition to changes in the social networks of adults within a community, children's own social networks may be affected during an economic downturn. If a child's peer or classmate was directly affected by parental job loss, that peer or classmate may have exhibited increased behavior problems (e.g., 39). In one study, students' disruptive classroom behaviors increased their classmates' disruptive behaviors and decreased their classmates' academic achievement (40).

\section{Variations Across Individuals and Communities}

Economic downturns may affect some children more than others. For example, economic downturns are consistently associated with negative outcomes for younger children but yield more mixed effects on adolescents. Other individual differences should also be considered, including children's gender (as suggested by 1), pre-existing economic well-being, and proximity to directly affected adults, among others. Boys and girls experience different socialization around work and family responsibilities, which could lead to differential effects of economic downturns. Additionally, children in families with lower levels of pre-existing economic well-being may be affected more strongly because their families may be less able to buffer them from the effects of economic downturns.

Another individual difference to consider is families' economic well-being after an economic downturn. Research needs to distinguish the impact of economic change from the impact of the reduced economic state produced by the change. Similarly, research also needs to examine how communities' economic strength during and after an economic downturn moderates effects on individuals in those communities.

Overall, patterns of findings are consistent across geographic units within the United States, including cities, counties, and states. This could be for statistical reasons because state-level effects are the aggregate of smaller, community-level (e.g., cities, counties) effects, and reflect the average across these smaller geographic units within a state. But meaningful effects could also exist at the state level. Where individuals live (i.e., in which state) is a meaningful marker of identity: States are the geographic units within which people pay taxes, receive public benefits, and are subject to laws. State budgets are publicly crafted and debated. So statewide economic downturns may influence all state residents to some degree. Across the studies we reviewed, within either smaller or larger geographic units, an economic downturn could lead to changes that affect children whose parents were not directly affected by job loss.

Researchers have examined the effects of economic downturns in other developed countries, primarily nations in Western Europe (25). In general, effects are similar to those found in the United States, but smaller, likely because the social safety net is stronger in the other countries. Developing countries also experience economic downturns that likely affect communities, individuals, and social networks. However, we hesitate to draw conclusions about how downturns affect children in developing countries because many of those countries have larger informal labor markets and fewer policy supports. Thus, the mechanisms proposed here may not apply to developing countries.

\section{LOOKING AHEAD AT RESEARCH}

Little research has examined how economic downturns lead to community-level structural changes. In particular, little is known about how the provision and availability of social services - important supports for children's behavioral and emotional development-change during downturns. Given that many social services are provided by cities and states - rather than nationally - focusing on local variation in economic conditions is paramount. Researchers should understand how economic downturns lead to structural changes in communities, and explore different types of structural changes that could affect different domains of child development.

Similarly, although economic downturns likely affect children through the strain they place on both adults' and children's social networks, little research has examined the impacts of downturns on social networks. Researchers should identify which social networks are affected during downturns and how those networks function differently following downturns. Such research should examine adults' and children's social networks separately, and explore mechanisms linking change in both types to children's development.

Finally, across all substantive areas, researchers should use methods that allow causal inference. Because communities are not randomly assigned to experience economic downturns, researchers should focus on robust quasi-experimental designs. Longitudinal designs that capture change in communities' economic conditions are stronger than cross-sectional designs that measure only point-in-time status. Using longitudinal data, researchers can include in their analyses fixed effects for communities, which control for all measured and unmeasured stable community characteristics that would otherwise bias estimates. To clarify the mechanisms linking communitywide economic 
downturns to children's development, new data collection efforts should gather information from individuals who have lost jobs and those who remain employed in different communities over time.

\section{POLICY IMPLICATIONS}

Our review suggests that to fully address the effects of economic downturns, policymakers should consider some changes to the types of interventions they typically use. For example, in response to high rates of job loss, the U.S. government provides Trade Adjustment Assistance, which helps local communities retrain workers who have lost jobs. Policymakers should focus on others in the community as well, including adults who remain employed and children of the employed and unemployed. One promising approach in this area that is consistent with our focus on communitywide impacts is an emphasis on place-based policies, which recognize communities as systems and support a holistic, comprehensive approach to community well-being. This type of policy intervention could aid all children in a community by providing supports that assist all members of a community, including those who remain employed and those whose social network members have lost jobs.

\section{REFERENCES}

1. Elder, G. H., Jr. (1974). Children of the great depression: Social change in life experience. Chicago, IL: University of Chicago Press.

2. McLoyd, V. C. (1998). Socioeconomic disadvantage and child development. American Psychologist, 53, 185-204. doi:10.1037/0003066X.53.2.185

3. Bronfenbrenner, U. (1979). The ecology of human development. Cambridge, MA: Harvard University Press.

4. Gassman-Pines, A., Ananat, E. O., \& Gibson-Davis, C. M. (2014). Effects of statewide job losses on adolescent suicide-related behaviors. American Journal of Public Health, 104, 1964-1970. doi:10.2105/AJPH.2014.302081

5. Stevens, A. H., \& Schaller, J. (2011). Short-run effects of parental job loss on children's academic achievement. Economics of Education Review, 30, 289-299. doi:10.1016/j.econedurev. 2010.10.002

6. Levine, P. B. (2011). How does parental unemployment affect children's educational performance? In G. J. Duncan \& R. Murnane (Eds.), Whither opportunity? Rising inequality and the uncertain life chances of low-income children (pp. 315-335). New York, NY: Russell Sage Foundation.

7. Ananat, E. O., Gassman-Pines, A., \& Gibson-Davis, C. M. (2011). The effects of local employment losses on children's educational achievement. In G. J. Duncan \& R. Murnane (Eds.), Whither opportunity? Rising inequality and the uncertain life chances of lowincome children (pp. 299-313). New York, NY: Russell Sage Foundation.

8. Ananat, E. O., Francis, D. V., Gassman-Pines, A., \& Gibson-Davis, C. M. (2013). Children left behind: The effects of statewide job loss on student achievement. Cambridge, MA, NBER Working Paper No. 17104.
9. Ananat, E. O., Gassman-Pines, A., \& Gibson-Davis, C. M. (2013). The effect of local job loss on teenage birthrates: Evidence from North Carolina. Demography, 50, 2151-2171. doi:10.1007/s13524013-0231-3

10. Levine, P. B. (2001). The sexual activity and birth-control use of American teenagers. In J. Gruber (Ed.), Risky behavior among youths: An economic analysis (pp. 167-217). Chicago, IL: University of Chicago Press.

11. Ruhm, C. J. (2000). Are recessions good for your health? Quarterly Journal of Economics, 115, 617-650. doi:10.1162/ 003355300554872

12. Arkes, J., \& Klerman, J. A. (2009). Understanding the link between the economy and teenage sexual behavior and fertility outcomes. Journal of Population Economics, 22, 517-536. doi:10.1007/ s00148-007-0172-5

13. Arkes, J. (2007). Does the economy affect teenage substance use? Health Economics, 16, 19-36. doi:10.1002/hec.1132

14. Park, H., Twenge, J. M., \& Greenfield, P. M. (2014). The Great Recession: Implications for adolescent values and behavior. Social Psychological and Personality Science, 5, 310-318. doi:10.1177/ 1948550613495419

15. Giuliano, P., \& Spilimbergo, A. (2014). Growing up in a recession. The Review of Economic Studies, 81, 787-817. doi:10.1093/restud/ rdt040

16. Zippay, A. (1991). From middle income to poor: Downward mobility among displaced steelworkers. New York, NY: Praeger.

17. Stephens-Davidowitz, S. (2013). Unreported victims of an economic downturn. Unpublished paper, Harvard University, Department of Economics, Cambridge, MA.

18. Jackson, C. K., Johnson, R., \& Persico, C. (2014). The effect of school finance reforms on the distribution of spending, academic achievement, and adult outcomes. Cambridge, MA, National Bureau of Economic Research Working Paper No. w20118.

19. Black, D. A., McKinnish, T. G., \& Sanders, S. S. (2003). Does the availability of high-wage jobs for low-skilled men affect welfare expenditures? Evidence from shocks to the steel and coal industries. Journal of Public Economics, 87, 1921-1942. doi:10.1016/S00472727(02)00014-2

20. Moffitt, R. A. (2013). The Great Recession and the social safety Net. ANNALS of the American Academy of Political and Social Science, 650, 143-166. doi:10.1177/0002716213499532

21. Molnar, B. E., Cerda, M., Roberts, A. L., \& Buka, S. L. (2008). Effects of neighborhood resources on aggressive and delinquent behaviors among urban youths. American Journal of Public Health, 98, 1086-1093. doi:10.2105/ajph.2006.098913

22. Arulampalam, W. (2001). Is unemployment really scarring? Effects of unemployment experiences on wages. Economic Journal, 111, 585-606. doi:10.1111/1468-0297.00664

23. McKee-Ryan, F., Song, Z., Wanberg, C. R., \& Kinicki, A. J. (2005). Psychological and physical well-being during unemployment: A meta-analytic study. Journal of Applied Psychology, 90, 53-76. doi: dx.doi.org/10.1037/0021-9010.90.1.53

24. Blanchflower, D. G., \& Oswald, A. J. (1994). The wage curve. Boston, MA: Massachusetts Institute of Technology.

25. Catalano, R. F., Goldman-Mellor, S., Saxton, K., Margerison-Zilko, C., Subbaraman, M., LeWinn, K., Anderson, E. (2011). The health effects of economic decline. Annual Review of Public Health, 32, 431-450. doi:10.1146/annurev-publhealth-031210-101146

26. Lovejoy, M. C., Graczyk, P. A., O'Hare, E., \& Neuman, G. (2000). Maternal depression and parenting behavior: A meta-analytic 
review. Clinical Psychology Review, 20, 561-592. doi:10.1016/ S0272-7358(98)00100-7

27. Dooley, D., Catalano, R., \& Rook, K. S. (1988). Personal and aggregate unemployment and psychological symptoms. Journal of Social Issues, 44, 107-123. doi:10.1111/j.1540-4560.1988.tb02094.x

28. Datta, D. K., Guthrie, J. P., Basuil, D., \& Pandey, A. (2010). Causes and effects of employee downsizing: A review and synthesis. Journal of Management, 36, 281-348. doi:10.1177/01492 06309346735

29. Quinlan, M., \& Bohle, P. (2009). Overstretched and unreciprocated commitment: Reviewing research on the occupational health and safety effects of downsizing and job insecurity. International Journal of Health Services, 39, 1-44.

30. Kalil, A. (2013). Effects of the Great Recession on child development. ANNALS of the American Academy of Political and Social Science, 650, 232-250. doi:10.1177/0002716213 500453

31. Brooks-Gunn, J., Schneider, W., \& Waldfogel, J. (2013). The Great Recession and the risk for child maltreatment. Child Abuse \& Neglect, 37, 721-729. doi:10.1016/j.chiabu.2013.08.004

32. Lee, D., Brooks-Gunn, J., McLanahan, S. S., Notterman, D., \& Garfinkel, I. (2013). The Great Recession, genetic sensitivity, and maternal harsh parenting. Proceedings of the National Academy of Sciences of the United States of America, 110, 13780-13784. doi:10.1073/pnas.1312398110

33. Steinberg, L. D., Catalano, R., \& Dooley, D. (1981). Economic antecedents of child abuse and neglect. Child Development, 52, 975985

34. Lindo, J. M., Schaller, J., \& Hansen, B. (2013). Economic conditions and child abuse. Cambridge, MA, National Bureau of Economic Research Working Paper No. 18994.
35. Gottlieb, A., Pilkauskas, N., \& Garfinkel, I. (2014). Private financial transfers, family income, and the Great Recession. Journal of Marriage and Family, 76, 1011-1024. doi:10.1111/jomf.12134

36. Mykyta, L., \& Macartney, S. (2011). The effects of recession on household composition: "Doubling up" and economic well-being. Washington, DC, US Census Bureau, SEHSD Working Paper.

37. Haider, S. J., \& McGarry, K. (2006). Recent trends in resource sharing among the poor. In R. M. Blank, S. H. Danziger, \& R. F. Schoeni (Eds.), Working and poor: How economic and policy changes are affecting low-wage workers (pp. 205-232). New York, NY: Russell Sage Foundation.

38. Eckenrode, J., \& Gore, S. (1981). Stressful events and social support: The significance of context. In B. H. Gottlieb (Ed.), Social networks and social support (pp. 43-68). Beverly Hills, CA: Sage.

39. Hill, H. D., Morris, P. A., Castells, N., \& Walker, J. T. (2011). Getting a job is only half the battle: Maternal job loss and child classroom behavior in low-income families. Journal of Policy Analysis and Management, 30, 310-333. doi:10.1002/pam.20565

40. Sacerdote, B. (2011). Peer effects in education: How might they work, how big are they and how much do we know thus far? In E. A. Hanushek, S. Machin, \& L. Woessmann (Eds.), Handbook of the economics of education (Vol. 3, pp. 249-277). San Diego, CA: Elsevier.

\section{SUPPORTING INFORMATION}

Additional supporting information may be found in the online version of this article:

Table S1. Measures Commonly Used to Operationalize Economic Downturns. 